\title{
My Depressed Person (A Monologue)
}

A friend recommended a story by David Foster Wallace called "The Depressed Person." My friend has never been really depressed, although she is well aware that depression, psychotherapy, mental instability, clinical diagnoses, crazy behavior, internal pain, lack of self-esteem, alternative therapies, crystal-gazing, the whole nine yards of contemporary malaise and its panaceas are all around her. A keen student of her culture, she admired this story because its language is so dead-on and pulls you into an experience of psychotherapy. I know that others have found it insulting to that practice, but when I read it I did not see it that way, nor do I now, even knowing that in none of its manifestations was Freud's proliferating legacy able to save the story's author.

What I saw instead was a brilliant narrative (if something so painfully circular can be said to be a narrative at all) driven by the enactment of unremitting self-consciousness. Its forward motion proceeds at the pace of therapy, which is to say in a series of repetitions and involutions that border on the grotesque; a few developments along the way tug you forward, while the central character, the depressed person herself, never moves off the dime. No matter what happens she is at the bottom of a well and all she can see hear touch feel taste smell is herself. The brilliance of the story is its double action: the free indirect discourse of excruciating self-centeredness and the linguistic play around its ouroboric tedium. Reading it was painful and fascinating. First, there's the digressive style, and then the interminable footnotes that keep interrupting the flow of the narrative, which as I said is not flowing much at all. It's a problem, keeping the different tracks running along at the same time, jumping back and forth and up and down on the page. I finally gave up reading it the first time through and had to go back later. At one point a dramatic turn surprises the loose shape of the story, springing the traps of self-centeredness and skepticism toward psychotherapy and other professional techniques for easing mental anguish.

That's almost all I want to say about the story, because what really made it so riveting was my intimate and long-term association with 
a depressed person, someone I cannot do without in my life, who because of an unexpected event in her life, fell into a terrible condition and was physically and mentally down that bottomless well. Because we are so close, it was my experience too, and so there I was in the middle of what I first heard about in college as the mindbody problem, which is to say that it got to be hard to tell what was her and what was the depression, and where they were the same, and who or what exactly I was relating to or loving. I was part of it for two years (and I will add here that depression seems to me contagious like measles or the flu) but it was only toward the end of it that I read the story, not knowing, of course, how near the end I was, even though by then things seemed to be looking up.

Reading the story again when that time was over, it didn't seem as long or as familiar as it did when I was still in the world of a depressed person, that terrible hole of the self's dark side. What I noticed later was how different my depressed person was from the one in Wallace's story, which still seems a dazzling performance of how the depressed mind works: a closely described experience of intense mercilessness. For my depressed person the whole etiology was entirely different and also her relationship to the therapist, and her life circumstances, and her age. What was the same was the terrible self-referentiality of the disease, the shame, the sense of being demeaned, the conviction that no one else has ever suffered comparably, the inability to describe the actual pain, and the isolation.

OK, I have a little more to say about the story, which is that now I think it's more about the relationship to the therapist, which in this case ended with the therapist's suicide. Then the depressed person starts calling an old friend long distance who has some kind of fatal cancer, so she's probably going to die as well. This unexpected (indeed, over-the-top) deployment of transference goes beyond contagion to understanding high-level depression as a struggle with death. The story is not only not insulting to the professionals who take on the job-in its dark and comic virtuosity it speaks knowledge of the highest stakes. While I was caring for my depressed person, it was as if the person I loved and depended on for so much of my life had been taken away from me and I was just hanging on to this vestige of her that I was blindly sure would turn back into the normal person she had once been. There even were times when 
she was that person, and I could see her clearly, and I'm pretty sure she sometimes saw her real self, too.

Her therapist had moved to California several years prior to this very bad time and although available on the phone was unable to be part of her therapy at anywhere near the level described in the story. Other local therapists were unconvincing. Once I drove her out to a near suburb to see a man who had been recommended. It was a warm summer day and when we got there I sat in the car and read a book that happened to be on the dashboard while she went in. I left the car door open and occasionally my gaze would drift around the little parking lot of the mini-mall where the therapist's office was. I was a bit distracted by anxiety about where we were going to get some food. One other thing about her depression that was not part of Wallace's story was that she needed to eat all the time. Not neurotically or for comfort, but because it reduced the depression. She had been on Prozac for eight years, but then it stopped working and nothing else she tried worked either. Sometimes she'd try a new drug or homeopathic remedy and it would work for a day, after which she'd crash even worse, which meant for me she was totally gone, dazed, unaware almost of who I was, of my love for her, of the chair she was sitting on.

It gradually became clear, however, that when she started sliding in this direction (tears dripping, loss of attention, a strange silence-it was creepy) if she ate, this slippage would stop. Food turned out to be the only substance that worked consistently and without the side effects of a crash, or insomnia, or a weird buzzy feeling. Even natural stuff like St. John's Wort or other liquids in expensive little bottles with droppers had those effects; also the latest SSRI breakthrough. A top man at the top loony bin in the region recommended something that came in a big bottle and looked just like mouthwash. The first day it made her feel better. The second day she wandered into the living room and when I sat next to her on the brown couch under the window she hardly knew I was there or if she was. It was like talking to someone dangling over a cliff and trying to get her to hang on until the rescue team (nowhere in sight) arrived.

But food worked fine except of course for its own side effect, the weight gain, a porking up that was its own misery. Also, there was the relentless need to keep assembling food. You have no idea how hard it is to feed yourself a hearty meal seven times a day, particularly when you aren't feeling hungry and are in a complete swivet 
about the size jeans you now have to buy. Even for the two of us it was too hard. You have to keep thinking of what to buy and then what to do with it. Plus she wanted the food to be healthy and not fattening. Apparently the last thing to go when you are hanging off a cliff is anxiety about whether you're fat. This is a twist in the mind-body problem not taken up in past study of ancient philosophers, but nonetheless part of this story.

On that day in the parking lot, though, we just got some sandwiches from a local restaurant. There were skimpy flowering trees at the edges of the mini-mall. I took a brief and secret pleasure in them. After fifty minutes, my depressed person came out of the therapist-possibility's office and sat next to me in the front seat of the car. "How was it?" I asked. She snorted with laughter. "He thinks I'm a codependent maniac," she said. He had some other things to say as well, all of which shed new light on the situation as almost everything did, the situation being so very dark. We went over and over this new information as we drove to a nearby meadow and walked its trails through marshy places, through woods, and along a bike path. We took our water bottles and ate the sandwiches, but it's our laughter that I remember.

As the months went by she saw other therapists and tried other remedies. I talked to a highly qualified medical acquaintance who explained to me the vast superiority of ЕСT over anything else in curing depression. That means electroshock therapy, and we didn't go there. Even depressed, her brain is way too important for that. They don't know why it works, this high-powered psycho-medic told me, but we don't know why aspirin works either. On the other hand, I never knew anyone who actually said they were helped by having their head hooked up to electrodes regularly for ten or twelve weeks and losing bits of short-term memory, but aspirin I've tried myself. She ordered a book on the subject, which I read. It had pictures of electricity patterns rendered as squares, and neat profiles of patients the treatment would be good for. I couldn't see my depressed person anywhere in this text.

Once we visited a place that had been set up to be a friendly refuge for traumatized women to come and recover. They had groups all day long, which, unlike the depressed person in the story, my depressed person is a real maven for. She knows how to be in groups, to listen and to share and to have informal fellowship after- 
wards and to believe in the contact. So we were shown around this facility and saw the little white beds and the collections of stuffed animals some of the women had and peeked into a room where a group was in process. That day I was actually in worse shape than my depressed person. I was worn out and sad from all the nights of watching her suffering and the mornings of going to her house to get her out of bed where she was envying the dead, and talking on the phone and in restaurants analyzing the terrible precipitating event, which if you are curious was the end of a long marriage, but believe me it was the marriage and not the ending that had wrecked the serotonin re-uptake process. I wanted to talk a little more to the counselor who had showed us around, but my depressed person just wanted to get out of there. She couldn't see herself in one of those little beds or hanging out in those narrow halls. Which I could understand. It was not a cheerful spot, and they didn't seem to get it about the food problem.

She tried a lot of other things. She wasn't unwilling to exert herself to help herself. She drove all over the place seeing an acupuncturist, and a guy who did something to her spine, and a woman who proposed to cure depression by following eye movements. A homeopath wearing orange spectacles demonstrated how her muscles responded of their own accord to disturbing prompts based on the parts of her name. Everything worked and nothing worked. Time went by, and the fact of all this therapeutic culture out there offering hope and taking money and available for the client's evaluation was part of the time, part of what there was to do. Once someone came to the house and tried to help her get in sympathy with the cells in her body. This someone, who worked with heart patients and cancer patients in hospitals, had had measurable medical results from getting people to be in touch with their prenatal lives, when their fetal selves were being impacted by what was going on ex-utero and thus messing up their little cellular psyches. I had to leave the room while this was going on, even though it was an acquaintance of mine who was practicing this peculiar art and it had been my idea to have her come. We are talking desperation here, it must be obvious. On the other hand, there's also the mind-body thing, which is not just something that went out with Lucretius or Parmenides.

Anyway, you can see that the day when we walked around the meadow and laughed at what a codependent maniac she was 
stands out in my mind. It's not the only day of course, and I never really lost sight of our laughter. I have known my depressed person since she was born and if she slipped away from me I would not be myself anymore. It's just that if the effect of depression is this terrible self-devouring, self-centered blindness, the only way to be myself was to approach that center with her. Which brings me back to the terrible gift of David Foster Wallace's story: his knowledge of what it is to be lost to the grace of compassion. Choking on her own tail, in the hell of self-enclosure, his depressed person couldn't see how her center was shared and so her behavior is figured as grotesque, revolving alone in the same spot. Ouroboros. Just so do the therapies that deal with depression come to appear grotesque (like ceremonies in other cultures, witch doctors and couvade and voodoo)—first comic, and then deadly.

And yet the story is alive and funny as well as grotesque, its dark art lit by the cosmic comedy of separateness. Which is surely why my friend recommended it. She is quick and funny herself and appreciates speed and humor in others. And so is my dear depressed person quick and funny even though a codependent maniac, so our walk around the meadow with our water bottles was really fun and I was absorbed and amused by her story about the therapist and his new information, his perspective on her case. I bet he would have been surprised to see us enjoying our walk, although perhaps not. Freud himself, after spinning out one nutty (although interesting) theory about the death instinct after another-and actually calling the essay "Beyond the Pleasure Principle," which makes you think it's going to be about some higher fun-essentially shrugs his shoulders and says, "What we cannot reach flying we must reach limping." And, if you were wondering, that sudden, expressive freedom of gait is what I mean by the grace of compassion.

So, imagine us limping around the meadow and along the bike path, tracing a narrow road inside the borders of the pleasure principle, while all around us time disguised itself as catkins and marsh plants and former children whirring by on rollerblades. Imagine my depressed person's serotonin levels responding to the burning of calories or to the invisible planetary alignment over our heads or just to our being together in our own long, digressive, circular, and finally shapeless story. 